\title{
Natural parasitism of Hexacladia smithii Ashmead (Hymenoptera: Encyrtidae) on Euschistus heros (F.) (Hemiptera: Pentatomidae): new record from Mato Grosso State, Brazil
}

\author{
Parasitismo natural de Hexacladia smithii Ashmead (Hymenoptera: Encyrtidae) \\ sobre Euschistus heros (F.) (Hemiptera: Pentatomidae): novo registro no \\ estado do Mato Grosso
}

\author{
Leonardo Morais Turchen ${ }^{1 *}$, Vanessa Golin², Bruna Magda Favetti², Alessandra Regina Butnariu', \\ Valmir Antônio Costa ${ }^{3}$
}

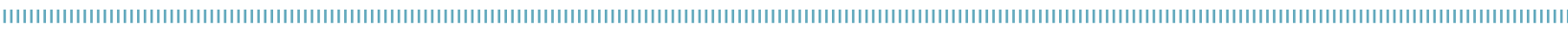

\begin{abstract}
The neotropical stink brown bug, Euschistus heros (F.) (Hemiptera: Pentatomidae), is an insect pest to soybean crops in Mato Grosso State, Brazil. In this region, synthetic insecticides are frequently used for insect control. An alternative to the indiscriminate use of insecticides is the biological control with parasitoids. Thus, the objective of this study was to conduct the survey of parasitoids that use $E$. heros adults as hosts. Random samples were conducted during the harvests of 2009/10 and $2010 / 11$ in two farms that produce soybean (conventional system) in Tangará da Serra, Mato Grosso State, Brazil. The total number of collected E. heros was: 297 (Field 1) and 293 (Field 2) in 2009/10 and 295 (Field 1) and 376 (Field 2) in 2010/11. Of these, 1.50 (Field 1) and 13.99\% (Field 2) were parasitized in 2009/10 and 8.47 (Field 1) and 7.45\% (Field 2) in 2010/11. The parasitoids found were Hexacladia smithii Ashmead (Hymenoptera: Encyrtidae) in both fields. This is the first record of parasitism in E. heros adults in the state of Mato Grosso, Brazil.
\end{abstract}

KEYWORDS: Pentatomidae; endoparasitoid; biological control; soybean.
RESUMO: O percevejo marrom, Euschistus heros (Hemiptera: Pentatomidae), é um inseto praga na cultura da soja no estado do Mato Grosso, Brasil. Nesta região, inseticidas sintéticos são frequentemente utilizados ao controle de insetos. Uma alternativa para o uso indiscriminado de inseticidas é o controle biológico com parasitoides. Assim, o objetivo deste estudo foi realizar o levantamento dos parasitoides que utilizam adultos de E. heros como hospedeiros. Para isso, amostras aleatórias foram conduzidas durante as safras de 2009/10 e 2010/11, em duas fazendas produtoras de soja (sistema convencional) em Tangará da Serra, Mato Grosso, Brasil. O número total de E. heros coletados foi: 297 (Área 1) e 293 (Área 2) em 2009/10 e 295 (Área 1) e 376 (Área 2) em 2010/11. Destes percevejos 1,50 (Área 1) e 13,99\% (Área 2) encontravam-se parasitados em 2009/10 e 8,47 (Área 1) e 7,45\% (Área 2) em 2010/11. Nas duas áreas, o parasitoide encontrado foi Hexacladia smithii Ashmead (Hymenoptera: Encyrtidae). Este é o primeiro registro de parasitismo em adultos de E. heros no estado do Mato Grosso, Brasil.

PALAVRAS-CHAVE: Pentatomidae; endoparasitoide; controle biológico; soja. 
Euschistus heros (F.) (Hemiptera: Pentatomidae) is an insect pest of economic importance to soybean crops in Brazil, especially in Mato Grosso State. This is due to its abundance and the damage it causes to several crops (PANizzi; Slansky, 1985; Corrêa-Ferreira; Azevedo, 2002; Vivan; Degrande, 2011). In this region, insecticides are generally used for arthropod pest control, mainly because of the efficiency of these products. However, they are often applied erroneously, which can contribute with negative impacts on the ecosystem and human health (BeLo et al., 2012). Hence, an alternative to use of insecticides is the implementation of other control tactics, such as biological (Kogan, 1998; Parra et al., 2002).

Before initiating the use of biological control against insect pests, it is necessary to know information about species in the region, such as their occurrence and abundances of natural enemies (Henneberry et al., 1991; Parra et al., 2002). Unfortunately, in the state of Mato Grosso, little is known about the natural enemies that control stink bug in adult stage. Thus, the objective of this study was to conduct a survey regarding parasitoids that use $E$. heros adults as hosts.

Random samples were conducted during the harvests of 2009/10 and 2010/11 in two farms that produce soybean in Tangará da Serra, Mato Grosso State, Brazil: Field $1-14^{\circ} 39^{\prime} \mathrm{S}$ and $57^{\circ} 24^{\prime} \mathrm{W}$; Field $2-14^{\circ} 18^{\prime} \mathrm{S}$ and $57^{\circ}$ $45^{\prime} \mathrm{W}$. Field 1 has always used pesticides (organophosphates and pyrethroids) to control pests, while Field 2 adopted an organic system between 2002 and 2009, but currently is using the conventional system. Adults of E. heros collected with shake cloth in Fields 1 and 2 were sent to the Laboratory of Entomology at the Universidade do Estado de Mato Grosso - Campus Tangará da Serra (UNEMAT/ CUTS). All the collected insects were individualized in plastic pots, where they received food and remained at environment temperature until emergence of parasitoids (or not). Hymenopterans were identified by Doctor Valmir Antônio Costa by employing the taxonomic key of Noyes (2010), and the specimens were deposited in the Collection of Entomophagous Insects "Oscar Monte" (IB-CBE), of the Biological Institute in Campinas, state of São Paulo.

The total number of $E$. heros sampled in the 2009/10 season was 297 and 293 in Fields 1 and 2 respectively, and 295 and 376 insects in 2010/11 season in the same areas. The parasitism percentage was 1.5 (Field 1) and $13.9 \%$ (Field 2) in 2009/10, and 8.5 (Field 1) and 7.5\% (Field 2) in 2010/11. The parasitoid found was Hexacladia smithii (Ashmead) (Hymenoptera: Encyrtidae), which is an endoparasitoid of nymphs and adult stink bugs that can contribute to reduction of insect pest.
Hexacladia smithii occurs from Argentina (De SANTIS, 1979) to Southern USA (Gordh, 1979), although Noyes (2010) considers this last record a result of an erroneous identification. These parasitoids were recorded from the South to the Central region of Brazil, in different cultures, and are associated with the control of Holymenia histrio (F.) (Hemiptera: Coreidae) and Anisoscelis marginella foliacea (Dallas) (Hemiptera: Coreidae), passion fruit pests (BALDin et al., 2010); Arvelius albopunctatus (De Geer) (Heteroptera: Pentatomidae), a tomato pest (Panizzi; Silva, 2010); and Dichelops furcatus (F.) (Hemiptera: Pentatomidae) and E. heros, soybean pests (CorrêA-Ferreira et al., 1998; Godoy et al., 2010; Panizzi; Silva, 2010).

This species is relatively considered polyphagous, because parasite nymphs and adults of various species of stink bugs are found in diverse crops (Coreidae, Pentatomidae and Scutelleridae). Its hosts are known: Holymenia clavigera (Herbst) (Hemiptera: Coreidae) (Costa Lima, 1930), Holymenia histrio (F.) (Hemiptera: Coreidae) and Anisoscelis marginella foliacea (Dallas) (Hemiptera: Coreidae) (BALdin et al., 2010); Antiteuchus sp. (Hemiptera: Pentatomidae) (Noyes, 2010); Antiteuchus mixtus (F.) [= Antiteuchus variolosus (Westwood)] (Hemiptera: Pentatomidae) (Cuezzo; Fidalgo, 1997); A. albopunctatus (Panizzi; Silva, 2010), Edessa sp. (Hemiptera: Pentatomidae) (De Santis, 1980; Noyes, 2010); Edessa meditabunda (F.) (Hemiptera: Pentatomidae) (Cuezzo; Fidalgo, 1997); E. heros (CorrêAFerreira et al., 1998; Mouráo; Panizzi, 2000) and D. furcatus (Panizzi; Silva, 2010); Pachycoris torridus (Scopoli) (Hemiptera: Scutelleridae) (Costa Lima, 1930) and Tetyra pinguis (Germar) (Hemiptera: Scutelleridae) (De Santis, 1979).

In summary, this research reported the first occurrence of $E$. heros adults parasitism in Mato Grosso State, Brazil. The results showed a low parasitism rate in $E$. heros adults ( 1.5 to $13.9 \%$ in $2009 / 10$ and 8.5 to $7.5 \%$ in $2010 / 11$ ). However, it contributes with knowledge about the diversity of beneficial insects in soybean crops and reinforces the need of further investigations, since these organisms can act on the agroecosystem balance and favor the reduction of insect pest population.

\section{ACKNOWLEDGMENTS}

To Franciosi group and Universidade do Estado de Mato Grosso for logistical support, to Fundação de Amparo à Pesquisa do Estado de Mato Grosso for financing the research. 


\section{REFERENCES}

ASHMEAD, W.H. An encyrtid with six-branched antennae. Insect Life, v.3, p.455-457, 1891.

BALDIN, E.L.L.; FUJIHARA, R.T.; BOICA, A.L.; ALMEIDA, M.C. Parasitismo de percevejos-praga do maracujazeiro no Brasil por Hexacladia smithii Ashmead (Hymenoptera: Encyrtidae). Neotropical Entomology, v.39, p.306-307, 2010.

BELO, M.S.S.P.; PIGNATI, W.; DORES, E.F.G.C.; MOREIRA, J.C.; PERES, F. Uso de agrotóxicos na produção de soja do Estado do Mato Grosso: um estudo preliminar de riscos ocupacionais e ambientais. Revista Brasileira de Saúde Ocupacional, v.37, p.78-88, 2012.

CORRÊA-FERREIRA, B.S.; AZEVEDO, J. Soybean seed damage by different species of stink bugs. Agriculture and Forest Entomology, v.4, p. 145-150, 2002.

CORRÊA-FERREIRA, B.S.; NUNES, M.C.; UGUCCIONI, L.D. Ocorrência do parasitoide Hexacladia smithii Ashmead em adultos de Euschistus heros (F.) no Brasil. Anais da Sociedade Entomológica do Brasil, v.27, p.495-498, 1998.

COSTA LIMA, A. Sobre insetos que vivem em maracujás (Passiflora spp.). Memórias do Instituto Oswaldo Cruz, v.23, p.159-162, 1930.

CUEZZO, F.; FIDALGO, P. Hexacladia smithii Ashmead (Hymenoptera: Encyrtidae): a new record for Argentina and two new pentatomid hosts recorded, Antiteuchus variolosus Westwood and Edessa meditabunda(F.) (Hemiptera: Pentatomidae), The Entomologist, v.116, p.11-14, 1997.

DE SANTIS, L. Catálogo de los himénopteros calcidoideos de América al sur de los Estados Unidos. La Plata: Publicación Especial Comisión de Investigaciones Cientificas, Provincia de Buenos Aires, 1979.488p.

DE SANTIS, L. Catálogo de los himenópteros brasilenos de la serie parasitica incluyendo Bethyloidea. Curitiba: Editora da Universidade Federal do Paraná, 1980. 187p.

GODOY, K.B.; ÁVILA, C.J.; DUARTE, M.M.; ARCE, C.C.M. Parasitismo e sítios de diapausa de adultos do percevejo marrom, Euschistus heros na região da Grande Dourados, MS. Ciência Rural, v.40, p. $1199-1202,2010$.
GORDH, G. Family Encyrtidae. In: KROMBEIN, K.V.; HURD, P.D. Jr.; SMITH, D.R.; BURKS, B.D. (Eds). Catalog of Hymenoptera in America North of Mexico. Washington: Smithsonian Institution Press, 1979. 958p.

HENNEBERRY, T.J.; VAIL, P.V.; PEARSON, A.C.; SEVACHERIAN, V. Biological control agents of noctuid larvae (Lepidoptera: Noctuidae) in the Imperial Valley of California. Southwest Entomologist, v.16, p.81-89, 1991.

KOGAN, M. Integrated pest management: historical perspectives and contemporary developments. Annual Review of Entomology, v.43, p.243-270, 1998.

MOURÃO, A.P.M.; PANIZZI, A.R. Diapause and different seasonal morphs of Euschistus heros (Fabricius) (Hemiptera: Pentatomidae) in Northern Paraná State. Anais da Sociedade Entomológica do Brasil, v.29, p.205-218, 2000.

NOYES, J.S. Encyrtidae of Costa Rica (Hymenoptera: Chalcidoidea), 3. Subfamily Encyrtinae: Encyrtini, Echthroplexiellini, Discodini, Oobiini and Ixodiphagini, parasitoids associated with bugs (Hemiptera), insect eggs (Hemiptera, Lepidoptera, Coleoptera, Neuroptera) and ticks (Acari). Gainesville, Florida. Entomological Institute, 2010. 848p.

PANIZZI, A.R.; SILVA, J.J. New records of pentatomids as hosts of Hexacladia smithii Ashmead (Hymenoptera: Encyrtidae) in southern Brazil. Neotropical Entomology, v.39, p.678-679, 2010.

PANIZZI, A.R.; SLANSKY Jr, F. Review of phytophagous Pentatomids (Hemiptera: Pentatomidae) associated with soybean in the Americas. Florida Entomology, v.68, p.184-214, 1985.

PARRA, J.R.P.; BOTELHO, P.S.M.; BOTELHO, B.S.; BENTO, J.M.S. Controle biológico no Brasil: terminologia, In: PARRA, J.R.P.; BOTELHO, P.S.M.; BOTELHO, B.S.; BENTO, J.M.S. (Eds.) Controle biológico no Brasil: parasitóides e predadores. São Paulo: Manole, 2002. p.1-16.

VIVAN, L.M.; DEGRANDE, P.E. Pragas da soja. Fundação MT Boletim de Pesquisa de Soja, v.11, p.239-297, 2011. 